\title{
Vegetation and White-tailed Deer Responses to Herbicide Treatment of a Mesquite Drain- age Habitat Type
}

\author{
SAMUEL L. BEASOM, JACK M. INGLIS, AND CHARLES J. SCIFRES
}

\begin{abstract}
A honey mesquite drainage habitat (20\% of a 1,215-ha study pasture) was aerially sprayed with $1.1 \mathrm{~kg} / \mathrm{ha}$ of 2,4,5-T + picloram in the spring. Adjacent habitats (blackbrush acacia uplands, creeping mesquite flats, blackbrush acacia-dominated mixed brush, and creeping mesquite-mixed brush) were not sprayed. Discriminant treatment of the honey mesquite drainage habitat did not cause consistent differences in white-tailed deer use of that habitat nor did it change deer use of the pasture containing the sprayed drainage based on average daily fecal accumulation rates for 22.5 months after herbicide application. Lack of differences in deer use between sprayed and unsprayed habitats were attributed to minor impacts of sprays on forb populations during the study period, retention of ample cover screen for deer, and increased abundance of grasses on sprayed areas which presumably reduced use of preferred deer food items by cattle.
\end{abstract}

The recent surge in economic potential of white-tailed deer (Odocoileus virginianus), especially in Texas, has precipitated intense interest in the potential effects of brush control on deer populations. Historically, the primary goal of brush control has been to improve range forage resources or to facilitate their use by livestock (Vallentine 1971). Consequently, most research efforts on interrelationships between brush control and white-tailed deer habitat have been oriented toward threshold levels of woody plant removal relative to their negative impacts on deer numbers.

Broadcast applications of selective herbicides have little immediate effect on screening cover and complete defoliation may require a month or longer. Consequently, aerial spraying of brush apparently has less acute impact on white-tailed deer numbers than do many conventional mechanical brush control methods. Aerial spraying of approximately $80 \%$ of mixed brush in alternating strips on areas of 430 to 1,800 ha in south Texas did not cause a net change in white-tailed deer popultions (Beasom and Scifres 1977 , Marshall 1978, McKenney 1978, Tanner et al. 1978). These studies, as with most in the past, evaluated treatments which were generally indiscriminant relative to range sites or habitats.

The antithesis of the deer-threshold brush cover relationship is the minimum amount of brush that can be controlled and result in an economically justifiable response to the landowner. This view generates several additional hypotheses which have not been tested. Since vegetation response to brush control is site specific (Scifres 1980), one proposition is that treatment only of range sites with greatest potential for herbaceous forage production (sites which frequently occupy a relatively small area) could increase livestock carrying capacities as much as, or more than, indiscriminant treatment of large portions of a pasture or ranch. However, in

\footnotetext{
At the time of the research, the authors were associate professor and professor, Department of Wildlife and Fisheries Sciences; and professor, Department of Range Science. Texas A\&M University, College Station, 77843.

Authors are grateful to P.H. Welder for furnishing land and herbicide treatment for the research, J.L. Mutzh and $K$. Caerely for their assistance in conducting the research, and Julia Scifres for manuscript typing and preparation.

Manuscript received August 2.1981
}

much of south and west Texas, the sites with greatest potential for producing herbaceous forages, such as the honey mesquite drainages, are also considered the most important habitat type for white-tailed deer (McMahan and Inglis 1974, Darr and Klebenow 1975). Consequently, managers often have controlled brush on all but these habitats to avoid possible reductions in deer numbers and/or quality. In such cases, resultant brush removal from a pasture may approach 70 to $90 \%$. This research was designed to test the hypothesis that chemical brush control could be applied to the honey mesquite drainages without negatively influencing deer numbers if adjacent habitats were not sprayed.

\section{Study Area}

This study was conducted on the Camaron Ranch in eastern LaSalle County, about $197 \mathrm{~km}$ south of San Antonio, Tex. (Fig. 1). The elevation is approximately $250 \mathrm{~m}$, and the topography is level to gently rolling. Average annual rainfall is about $53 \mathrm{~cm}$, with a peak usually occurring in late spring and another in late summerearly fall.

Study pastures were 1,376 and 1,134 ha and consisted of honey mesquite drainages, blackbrush acacia (Acacia rigidula) uplands, creeping mesquite (Prosopis glandulosa var. reptans) flats, blackbrush acacia-dominated mixed brush, and creeping mesquitemixed brush as the major habitats (Fig. 1). Woody species which occurred in all habitats were Texas pricklypear (Opuntia lindheimeri), lotebush (Ziziphus obtusifolia), knifeleaf condalia (Condalia spathulata), guayacan (Porlieria angustifolia), spiny hackberry (Celtis pallida) and twisted acacia (Acacia tortuosa). Whitebrush (Aloysia lycioides), Texas paloverde (Cerdidium texanum), and retama (Parkinsonia aculeata) occurred prima rily in the honey mesquite drainages.Guajillo (Acacia berlandieri), ceniza (Leucophyllum frutescens), and bumelia (Bumelia celastrina) occurred primarily on the blackbrush acacia uplands. Plant nomenclature follows Gould (1975).

Range condition was generally poor to low fair at initiation of the study. The pastures were grazed yearlong at $1 \mathrm{AU} / 8$ ha as a part of a cow-calf operation. The deer density in the general area was reportedly 10 to $11 \mathrm{ha} /$ animal (McMahan and Inglis 1974).

\section{Methods}

Approximately $70 \%$ ( $243 \mathrm{ha}$ ) of the mesquite drainage type in the larger pasture (about $20 \%$ of the total land area) was aerially sprayed on May 27,1977 with $1.1 \mathrm{~kg} / \mathrm{ha}$ (total herbicide) of 2,4,5-T [(2,4,5-trichlorophenoxy)acetic acid] + picloram (4-amino-3,5,6tricholorpicolinic acid) as a 1:1 commercial mixture in $37 \mathrm{~L} /$ ha of a diesel oil L/ ha of a diesel oil:water (1:3) emulsion. During the first week of June 1977 , canopy cover by woody species was recorded at 100 , equally spaced points down the center of the treated and untreated drainages using the point-centered quarter method (Cottam and Curtis 1956). Canopy diam of the nearest woody plant in each quadrat was converted to canopy area, and average area per 

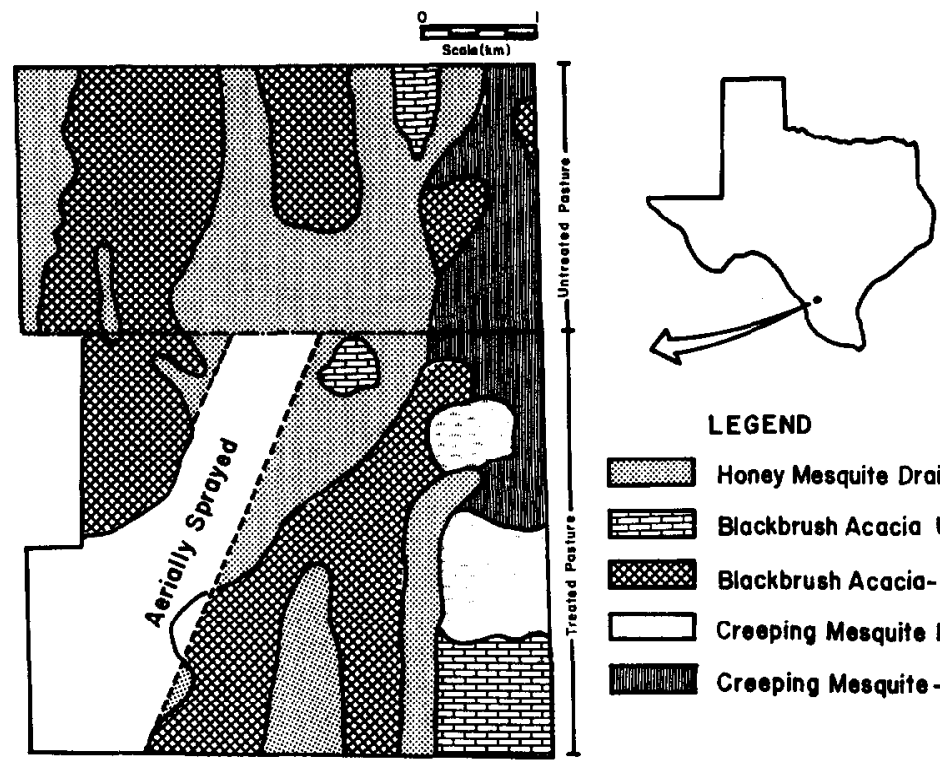

LEGEND

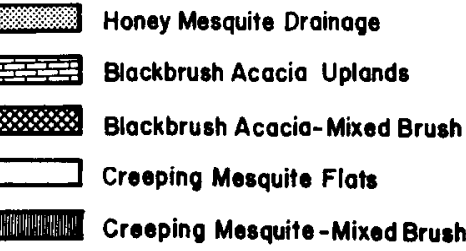

Fig. 1. Position of honey mesquite drainage sprayed with $1.1 \mathrm{~kg} / \mathrm{ha}$ of $2,4,5-T+$ picloram (I:I)inrelation tootherhabitats near Cotulla, Texas.

plant was multiplied by the plant density for the habitat to derive canopy cover.

Thirty grazing exclosures, $3.7 \mathrm{~cm}$ in circumference and $1.4 \mathrm{~m}$ tall and constructed of wire mesh with $10-\mathrm{cm}$ openings, were equidistantly spaced along a line through the long axis of the sprayed area. Thirty such exclosures were also established in untreated mesquite drainage within $100 \mathrm{~m}$ of the edge of the treated area and on lines parallel to those in the sprayed drainage. Standing crops of herbaceous vegetation were harvested at 4,15 , and 27 months after herbicide application by clipping a $0.25-\mathrm{m}^{2}$ a rea to a $2.5 \mathrm{~cm}$ stubble height from the center of each exclosure. Based on random selection of one of the cardinal directions, a $0.25-\mathrm{m}^{2}$ unprotected area 1 $\mathrm{m}$ from each exclosure was also harvested. The exclosures were then relocated, based on random selection of the cardinal directions, $10 \mathrm{~m}$ from the original location. Grazing activities of livestock disturbed some of the exclosures so that sample numbers ranged from 19 to 29 per treatment among sampling times. Herbage was separated into grasses and forbs, dried at $100^{\circ} \mathrm{C}$ for 48 hours, and weighed.

Relative density indices of forbs were determined by visual assessment at approximately 6-week intervals from April 1977 through April 1979 on circular $30-\mathrm{m}^{2}$ plots (72 in the sprayed area, 234 in the untreated portion of the sprayed pasture, and 222 in an adjacent untreated pasture). Plot locations were stratified by habitat but sampling points were randomly placed within the brush stands. Arbitrary abundance classes (plants/plot were $0=$ none, $I$ $=1-5,2=6-50,3=51-500,4=501-5,000$, and $5=$ over 5,000 . Treatment effects were evaluated by analysis of variance across sampling periods.

Canopy cover reductions of woody plants by species were estimated in September 1977, May 1978, and July 1979 in ten, 15-mwide by $156-\mathrm{m}$-long sampling areas which were equidistantly spaced through the long axes of the treated and untreated honey mesquite drainages. Percentage canopy reductions by species between treatments within years were compared by $t$-test $(P \leq .05)$.

Relative deer abundance between pastures and between treatments of habitat types within pastures was evaluated by fecal pellet group accumulation on the vegetation plots. The initial evaluation (1 month pretreatment) represented all fecal groups that had accumulated prior to the study and could be used only as a relative indicator of previous deer use among habitats. Since fecal groups were removed after each assessment, subsequent data were reported as average number of groups accumulated per plot per day. The evaluation periods coincided with assessments of forb stands on the plots. McMahan (1973) reported deer pellet group accumulation data on plots in a nearby area to be distributed as a negative binomial. Therefore, the raw data were transformed by the inverse hyperbolic sin (C.E. Gates, pers. commun.) by the formula $\sin ^{-1} \sqrt{y+1 / 2}=\ln (\sqrt{y+1 / 2}+\sqrt{y+3 / 2})$ where $y=$ observed count and $\ln =\log _{\mathrm{e}}$ prior to conducting a nalysis of variance. Means of transformed data were sepa rated by Duncan's multiple range test (Steel and Torrie 1960).

\section{Results}

Woody plant canopy cover averaged $46 \%$ at the time of herbicide application to the honey mesquite drainage. Proportions of the woody cover by species were honey mesquite, $42 \%$; pricklypear, 16\%; hlackbrush acacia, 15\%; spiny hackberry, $11 \%$; and twisted acacia, $8 \%$. Lotebush condalia, guayacan, knifeleaf condalia, and Texas paloverde each accounted for less than $3 \%$ of the woody plant canopy cover.

Average canopy reduction of woody plants and percentage of plants completely defoliated and not sprouting from stem bases (plants killed) varied widely among species. Average canopy reductions of honey mesquite, spiny hackberry and Texas paloverde ranged from 90 to $100 \%$ throughout the study period (Table 1). The responses of the three former species are consistent with previous research results (Scifres et al. 1977) but less is known concerning

Table 1. Average percentage estimated canopy reduction (CR) of woody plants and percentage of the population completely defoliated and not sprouting from stem bases (TD) at various times after aerially spraying a honey mesquite drainage habitat with $1.1 \mathrm{~kg} / \mathrm{ha}$ of $2,4,5-\mathrm{T}+$ picloram on May 22, 1977, on the South Texas Plains.

\begin{tabular}{|c|c|c|c|c|c|c|}
\hline \multirow[b]{3}{*}{ Woody species } & \multicolumn{6}{|c|}{ Months after herbicide application } \\
\hline & \multicolumn{2}{|r|}{4} & \multicolumn{2}{|r|}{12} & \multicolumn{2}{|r|}{26} \\
\hline & CR & TD & CR & TD & $\mathrm{CR}$ & TD \\
\hline Honey mesquite & $95^{*}$ & $90^{*}$ & $98^{*}$ & $80^{*}$ & $93^{*}$ & $82^{*}$ \\
\hline Twisted acacia & $92^{*}$ & $33^{*}$ & $82 *$ & $26^{*}$ & 74* & $14^{*}$ \\
\hline Blackbrush acacia & $70^{*}$ & $40^{*}$ & $90^{*}$ & $30^{*}$ & 94* & $32 *$ \\
\hline Lotebush & $75^{*}$ & 0 & 12 & 0 & $23^{*}$ & 0 \\
\hline Guayacan & 0 & 0 & 0 & 0 & 0 & 0 \\
\hline Knifeleaf condalia & 0 & 0 & 12 & 0 & 0 & 0 \\
\hline Spiny hackberry & $95^{*}$ & 0 & $100^{*}$ & $48^{*}$ & $92 *$ & $82^{*}$ \\
\hline Texas paloverde & $90^{*}$ & $85^{*}$ & $100^{*}$ & $100^{*}$ & $100^{*}$ & $98^{*}$ \\
\hline Texas pricklypear & 0 & 0 & $82 *$ & 0 & $89 *$ & $78^{*}$ \\
\hline
\end{tabular}

'Asterisked means indicted significant reduction $(P \leq .05)$ compared to untreated stands based on $t$-test. 
the response of Texas paloverde to 2,4,5-T/picloram mixture. Blackbrush acacia and Texas pricklypear responded more slowly than did honey mesquite to the aerial spray, but average reduction in live aerial parts exceeded $80 \%$ by 12 and 26 months after herbicide application. Canopy reduction of twisted acacia averaged $92 \%$ at 4 months after treatment but the species had recovered somewhat during the second and third growing season. Although initial canopy reduction averaged $75 \%$, lotebush was only partially controlled by the treatment; and gauyacan and knifeleaf condalia were essentially unaffected.

Based on percentage of the population completely defoliated and not sprouting from the bases, reduction of live honey mesquite at 26 months after spraying in this study $(73 \%$, Table 1$)$ was greater than the long-term average (42\%, Scifres 1973). Likewise, percentage of spiny hackberry plants killed was higher than reported in previous research (Scifres et al. 1977). Thus, relative to response of woody plants, the herbicide trea tment was deemed highly effective.

Annual rainfall was $38.5 \mathrm{~cm}$ (73\% of the long-term average) during $1977,65.3 \mathrm{~cm}$ in 1978 (124\% of the long-term average), and was $34.3 \mathrm{~cm}$ in 1979 . Standing crops of grasses were increased $(P \leq 0.05) 3.5$ to 9.7 fold on the aerially sprayed honey mesquite drainage compared to those from the similar but untreated habitat, regardless of evaluation time (Table 2). Rainfall during the period from herbicide application to first harvest of grasses was $22 \mathrm{~cm}$. The greatest difference in grass standing crop between sprayed and unsprayed drainages occurred in late July 1979, 15 months after initiation of the study (Table 2). During the 60-day period preceding this harvest, approximately $24 \mathrm{~cm}$ of rainfall were received.

Average forb standing crop was reduced $(P \leq 0.05)$ on the sprayed drainage, compared to that on the unsprayed drainages during the growing season of herbicide application (Table 2). Forb standing crops were low, regardless of treatment, the second and third growing seasons of study.

Average forb density indices are presented so that comparisons of (1) sprayed with untreated honey mesquite drainages, (2) sprayed drainage with untreated uplands in the pasture containing the sprayed drainage, and (3) overall average forb abundance of whole pastures, whether partially sprayed or untreated, are possible (Table 3). Forb densities on the sprayed and untreated drainages were roughly equivalent or were greater on sprayed drainages except during the growing season of herbicide application. During the period from spraying to 4.75 months posttreatment, forb abundance on the sprayed drainage was reduced compared to those on
Table 2. Oven-dry standing crop of grasses and forbs on honey mesquite drainage habitat at various times after aerially spraying with $1.1 \mathrm{~kg} / \mathrm{ha}$ of 2,4,5-T + picloram on May 22, 1977, compared to adjacent untreated habitat on the South Texas Plains.

\begin{tabular}{|c|c|c|c|c|}
\hline \multirow{3}{*}{$\begin{array}{l}\text { Months post } \\
\text { treatment }\end{array}$} & \multicolumn{4}{|c|}{ Standing crop $(\mathrm{kg} / \mathrm{ha})^{\prime}$} \\
\hline & \multicolumn{2}{|c|}{ Grasses } & \multicolumn{2}{|c|}{ Forbs } \\
\hline & Sprayed & Untreated & Sprayed & Untreated \\
\hline $\begin{array}{r}4 \\
15 \\
27\end{array}$ & $\begin{array}{l}1,418^{*} \pm 134 \\
3,086^{*} \pm 201 \\
1,131^{*} \pm 111\end{array}$ & $\begin{array}{l}403 \pm 67 \\
319 \pm 49 \\
292 \pm 81\end{array}$ & $\begin{array}{c}100^{*} \pm 6 \\
11 \pm 8 \\
T^{2}\end{array}$ & $\begin{array}{c}203 \pm 20 \\
6 \pm 3 \\
T\end{array}$ \\
\hline
\end{tabular}

'M cans marked by asterisk are significantly different $(I \leq .05)$ from those of untreated area at the same sampling time.

${ }^{2} \mathrm{~T}=$ trace, less than $5 \mathrm{~kg} / \mathrm{ha}$.

untreated drainages (Table 3), as were standing crop of forbs (Table 2). However, the tendency from 9 to 22.5 months after spraying was for forbs to be more abundant on the sprayed than on the untreated drainage (Table 3). Comparison of average forb indices between the sprayed honey mesquite drainage and the upland habitat type paralleled differences between sprayed and untreated honey mesquite drainages. Comparison between whole pastures indicated no appreciable pasturewide effect of spraying on average forb abundance.

The pellet group data provided the same 3 types of comparisons as did the forb density indices. The high intensity use of drainages relative to adjacent untreated uplands demonstrates a typical pattern of habitat selection by white-tailed deer on the South Texas Plains. This use pattern was not changed by aerial spraying with 2,4,5-T + picloram. Comparison of fecal accumulation rates between sprayed and untreated honey mesquite drainages indicates no early negative response of white-tailed-deer to the brush treatment with the possible exception of reduced use of treated drainages at 6 to 8 months after treatment (Table 4). The tendency after 1 year was for pellet group accumulation rates to be greater on the sprayed than on the untreated drainage. Pasturewide comparisons suggest that deer may have reduced their relative use of the pasture containing the sprayed drainage from 5 to 10 months after herbicide application. However, overall difference in pasture use by deer in response to spraying of the honey mesquite drainage was minor. Any expectation that deer would be driven out of the sprayed honey mesquite drainage, either acutely or chronically,

Table 3. Average forb density indices on: (1) a honey mesquite drainage habitat which was aerially sprayed on May 22,1977 , with $1.1 \mathrm{~kg} / \mathrm{ha}$ of $2,4,5-\mathrm{T}+$ picloram, (2) an untreated hahitat adjacent to the mesquite drainage, (3) an untreated mesquite drainage in an adjacent pasture, (4) the entire pasture containing the sprayed drainage, and (5) an entire, adjacent untreated pasture.

\begin{tabular}{|c|c|c|c|c|c|}
\hline \multirow{3}{*}{$\begin{array}{l}\text { Months post } \\
\text { treatment }\end{array}$} & \multicolumn{5}{|c|}{ Forb density index } \\
\hline & \multicolumn{2}{|c|}{ Mesquite drainage } & \multirow{2}{*}{$\begin{array}{l}\text { Untreated habitat of } \\
\text { pasture containing } \\
\text { sprayed drainage }\end{array}$} & \multirow{2}{*}{$\begin{array}{c}\text { Entire pasture } \\
\text { which contained } \\
\text { sprayed drainage }\end{array}$} & \multirow{2}{*}{$\begin{array}{c}\text { Entire pasture, } \\
\text { untreated }\end{array}$} \\
\hline & Untreated & Sprayed & & & \\
\hline-1.00 & $2.6 \mathrm{a}^{1}$ & $2.4 \mathrm{a}$ & $2.9 \mathrm{~b}$ & $2.8 \mathrm{ab}$ & $2.5 \mathrm{a}$ \\
\hline 0.25 & $2.2 \mathrm{a}$ & $2.4 \mathrm{a}$ & $2.4 \mathrm{a}$ & $2.4 \mathrm{a}$ & $2.3 \mathrm{a}$ \\
\hline 1.75 & $2.0 \mathrm{~b}$ & $1.6 \mathrm{a}$ & $2.1 \mathrm{~b}$ & $2.0 \mathrm{~b}$ & $2.0 \mathrm{~b}$ \\
\hline 3.25 & $1.6 \mathrm{~b}$ & $0.8 \mathrm{a}$ & $1.3 \mathrm{~b}$ & $1.3 \mathrm{ab}$ & $1.5 \mathrm{~b}$ \\
\hline 4.75 & $1.7 \mathrm{c}$ & $1.0 \mathrm{a}$ & $1.2 \mathrm{~b}$ & $1.1 \mathrm{a}$ & $1.4 \mathrm{bc}$ \\
\hline 6.25 & $1.3 \mathrm{a}$ & $1.3 \mathrm{a}$ & $1.2 \mathrm{a}$ & $1.3 \mathrm{a}$ & $1.5 \mathrm{a}$ \\
\hline 7.50 & $0.8 \mathrm{a}$ & 0.9 & $0.9 \mathrm{a}$ & $0.9 \mathrm{a}$ & $0.8 \mathrm{a}$ \\
\hline 9.00 & $1.5 \mathrm{~b}$ & $2.8 \mathrm{c}$ & $1.1 \mathrm{a}$ & $1.5 \mathrm{~b}$ & $1.7 \mathrm{~b}$ \\
\hline 10.25 & $1.0 \mathrm{~b}$ & $1.9 \mathrm{c}$ & $0.8 \mathrm{ab}$ & $1.1 \mathrm{~b}$ & $0.7 \mathrm{a}$ \\
\hline 11.75 & $1.6 \mathrm{~b}$ & $1.7 \mathrm{~b}$ & $1.2 \mathrm{a}$ & $1.5 \mathrm{ab}$ & $1.8 \mathrm{~b}$ \\
\hline 13.00 & $1.7 \mathrm{a}$ & $2.0 \mathrm{a}$ & $1.9 \mathrm{a}$ & $2.0 \mathrm{a}$ & $2.0 \mathrm{a}$ \\
\hline 14.75 & $2.0 \mathrm{a}$ & $1.9 \mathrm{a}$ & $1.8 \mathrm{a}$ & $1.9 \mathrm{a}$ & $2.2 \mathrm{a}$ \\
\hline 16.50 & $1.3 \mathrm{a}$ & $1.7 \mathrm{a}$ & $1.6 \mathrm{a}$ & $1.7 \mathrm{a}$ & $1.4 \mathrm{a}$ \\
\hline 19.50 & $1.3 \mathrm{~b}$ & $1.5 \mathrm{~b}$ & $1.0 \mathrm{a}$ & $1.1 \mathrm{a}$ & $1.2 \mathrm{ab}$ \\
\hline 21.25 & $1.2 \mathrm{ab}$ & $1.9 \mathrm{c}$ & $1.4 \mathrm{ab}$ & $1.5 \mathrm{~b}$ & $1.1 \mathrm{a}$ \\
\hline 22.50 & $1.6 \mathrm{a}$ & $2.2 \mathrm{c}$ & $1.8 \mathrm{ab}$ & $1.9 \mathrm{~b}$ & $1.8 \mathrm{ab}$ \\
\hline
\end{tabular}

iMeans within a row, followed by the same letter are not significantly different $(P \leq 0.05)$ according to Duncan's multiple range test. 
was not demonstrated by these data. Rates of pellet group accumulation were higher on the adjacent pasture than on the pasture containing the sprayed drainage in only 4 of 16 sampling periods. Reductions in rate of pellet group accumulation in the treated pasture were probably attributable to inherent differences in its carrying capacity compared to the untreated pasture.

\section{Discussion}

Results from aerially spraying the mesquite drainage habitat in this study differ from those of Darr and Klebenow (1975) who reported that chaining of bottomlands in the Rolling Plains of Texas significantly reduced white-tailed deer numbers for several years, and that herbicides caused a negative resonse for 3 to 5 years. Obviously, chaining drastically reduces woody plants available for deer cover in bottomlands. However, relative impacts on deer use from one location to another doubtless result from the abundance and structure of available, untreated woody cover. Similarly, differing impacts attributable to herbicide use may result from differences in cover screen between the 2 situations after defoliation of the woody plants. Since an insignificant reduction in cover screen from 0 to $0.9 \mathrm{~m}$ (deer height) is noted after herbicide treatment of mesquite brushland (Tanner 1976), any reduction in cover screen in our study may have been mitigated by a general increase in available food supply.

The variable efficacy of herbicides because of differences among sprayed sites relative to soil water a vailability and soil type, age and species of woody plants, and weather factors has been documented (Fisher et al. 1953, Dahl et al. 1971, Scifres 1980). However, it is generally true that economically-acceptable herbicide treatments result in at least partially killing woody plant stands (Bovey et al. 1968; Meyer and Bovey 1973; Whitson and Scifres 1980). Frequently, resprouting from defoliated woody plants increases the amount and / or availability of browse (K refting and Hansen 1969) and new sprouts are preferred to mature branches by white-tailed deer (Powell and Box 1966). Resprouting browse plants generally also contain higher levels of protein, phosphorus, and total digestible nutrients than mature or decadent ones (Dietz 1972).

Although an indirect influence, the general increase in herbaceous vegetation probably also influenced food availability for white-tailed deer in this study. McMahan and Inglis (1974) con- cluded that forbs were the food items that most attracted deer utilization to range sites, given an adequate cover screen. The 3 to 10 -fold increase in grass abundance on the sprayed honey mesquite drainage should have improved conditions for deer by reducing cattle utilization of forbs and browse. Other studies with herbicides have reported an initial reduction in forbs followed by a return to pretreatment levels after several months (Beasom and Scif res 1977, Scifres et al. 1977), but a general increase apparently is uncommon.

From a management viewpoint, results herein suggest that aerially spraying honey mesquite drainage habitats in south Texas is a useful tool for increasing herbaceous forage for livestock. Moreover, such treatments when applied to about $20 \%$ of the land area in a pasture and leaving adjacent habitats undisturbed have negligible impact on white-tailed deer use. Thus, the hypothesis that preferred habitats such as the honey mesquite drainage can be aerially sprayed for brush management without a negative response by deer, if adjacent habitats are left undisturbed, cannot be rejected based on results of this study. Further, site-specific treatment appears advantageous in that only sites of greatest response potential are treated, thus reducing overall brush management costs, by exempting sites of lower forage production potential. However, it is suggested that site selection must be conducted on a case-by-case basis with cognizance of the relative importance of adjacent habitats for white-tailed-deer.

\section{Literature Cited}

Beasom, S.L., and C.J.Scifres. 1977. Population reactions of selected game species to aerial he rbicide applications in south Texas. J. Range Manage. 30:138-142.

Bovey, R.W., F.S. Davis, and H.L. Morton. 1968. Herbicid e combinations for woody plant control. Weed Sci. 16:332-335.

Cottom, G., and J.T. Curtis. 1956. The use of distance measures in phytosociological sampling. Ecology 37:451-460.

Dahl, B.E., R.B. Wadley, M.R. George, and J.L. Talbot. 1971. Influence of site on mesquite mortality from 2,4,5-T. J. Range Manage. 24:210-215.

Darr, G.W., and D.A. Klebenow. 1975. Deer, brush control, and livestock on the Texas Rolling Plains. J. Range Manage. 28:115-119.

Dietz, D.R. 1972. Nutritive value of shrubs. USDA FS Gen. Tech. Rep. INT-I. $494 \mathrm{p}$

Table 4. Deer pellet group accumulation rates on: (1) a honey mesquite drainage habitat which was aerially sprayed on May 22,1977 with $1.1 \mathrm{~kg} / \mathrm{ha}$ of 2,4,5-T + picloram, (2) an untreated habitat adjacent to the mesquite drainage, (3) an untreated mesquite drainage in an adjacent pasture, (4) the entire pasture containing the sprayed drainage, and (5) an entire, adjacent untreated pasture.

\begin{tabular}{|c|c|c|c|c|c|}
\hline \multirow{3}{*}{$\begin{array}{l}\text { Months post } \\
\text { treatment }\end{array}$} & \multicolumn{5}{|c|}{ Avg. pellet groups/plot day $(\times 100)$} \\
\hline & \multicolumn{2}{|c|}{ Mesquite drainage } & \multirow{2}{*}{$\begin{array}{l}\text { Untreated habitat of } \\
\text { pasture containing } \\
\text { sprayed drainage }\end{array}$} & \multirow{2}{*}{$\begin{array}{l}\text { Entire pasture } \\
\text { which contained } \\
\text { sprayed drainage }\end{array}$} & \multirow{2}{*}{$\begin{array}{l}\text { Adjacent entire } \\
\text { pasture, untreated }\end{array}$} \\
\hline & Untreated & Sprayed & & & \\
\hline$-1.00^{1}$ & $2.2 \mathrm{c}^{2}$ & $5.2 \mathrm{~d}$ & $0.8 \mathrm{a}$ & $1.7 \mathrm{bc}$ & $1.3 \mathrm{ab}$ \\
\hline 0.25 & $0.4 \mathrm{a}$ & $1.2 \mathrm{a}$ & $0.5 \mathrm{a}$ & $0.7 \mathrm{a}$ & $1.0 \mathrm{a}$ \\
\hline 1.75 & $0.3 \mathrm{a}$ & $0.3 \mathrm{a}$ & $0.7 \mathrm{~b}$ & $0.6 \mathrm{~b}$ & $0.5 \mathrm{~b}$ \\
\hline 3.25 & $1.0 \mathrm{bc}$ & $1.2 \mathrm{c}$ & $0.3 \mathrm{a}$ & $0.5 \mathrm{a}$ & $0.7 \mathrm{ab}$ \\
\hline 4.75 & $0.5 \mathrm{~b}$ & $0.5 \mathrm{~b}$ & $0.2 \mathrm{a}$ & $0.2 \mathrm{a}$ & $1.1 \mathrm{c}$ \\
\hline 6.25 & $2.1 \mathrm{~b}$ & $1.4 \mathrm{a}$ & $0.4 \mathrm{a}$ & $0.6 \mathrm{a}$ & $1.7 \mathrm{ab}$ \\
\hline 7.50 & $2.0 \mathrm{~b}$ & $1.1 \mathrm{a}$ & $1.0 \mathrm{a}$ & $1.0 \mathrm{a}$ & $2.4 \mathrm{~b}$ \\
\hline 9.00 & $2.2 \mathrm{~b}$ & $1.7 \mathrm{~b}$ & $0.8 \mathrm{a}$ & $1.0 \mathrm{a}$ & $1.6 \mathrm{~b}$ \\
\hline 10.25 & $1.1 \mathrm{ab}$ & $1.7 \mathrm{~b}$ & $0.6 \mathrm{a}$ & $0.9 \mathrm{a}$ & $0.7 \mathrm{a}$ \\
\hline 11.75 & $1.0 \mathrm{a}$ & $3.4 \mathrm{~b}$ & $1.1 \mathrm{a}$ & $1.5 \mathrm{a}$ & $1.0 \mathrm{a}$ \\
\hline 13.00 & $1.3 \mathrm{a}$ & $3.1 \mathrm{~b}$ & $0.8 \mathrm{a}$ & $1.3 \mathrm{a}$ & $1.4 \mathrm{a}$ \\
\hline 14.75 & $0.6 \mathrm{c}$ & $0.0 \mathrm{a}$ & $0.1 \mathrm{~b}$ & $0.1 \mathrm{~b}$ & $0.2 \mathrm{~b}$ \\
\hline 16.50 & $0.2 \mathrm{a}$ & $0.5 \mathrm{~b}$ & $0.3 \mathrm{a}$ & $0.3 \mathrm{a}$ & $0.3 \mathrm{a}$ \\
\hline 19.50 & $0.5 \mathrm{a}$ & $1.2 \mathrm{~b}$ & $0.4 \mathrm{a}$ & $0.6 \mathrm{a}$ & $0.3 \mathrm{a}$ \\
\hline 21.25 & $0.8 \mathrm{c}$ & $0.4 \mathrm{~b}$ & $0.2 \mathrm{a}$ & $0.3 \mathrm{ab}$ & $0.8 \mathrm{c}$ \\
\hline 22.50 & $0.8 \mathrm{ab}$ & $1.0 \mathrm{~b}$ & $0.5 \mathrm{a}$ & $0.6 \mathrm{ab}$ & $0.8 \mathrm{ab}$ \\
\hline Sample units & 54 & 74 & 222 & 296 & 222 \\
\hline
\end{tabular}

IPretreatment values are total pellet groups accumulated prior to sample date with no regard for time so they do not represent deposition rates. ${ }^{2}$ Means in row followed by the same letter are not significantly different $(P \leq 0.05)$ according to Duncan's multiple range test. 
Fisher, C.E., C.H. Meadors, and R. Behrens. 1953. Some factors that influcnce the effectiveness of 2,4,5-trichlorophenoxy-acetic acid in killing mesquite. Weeds 4:139-147.

Gates. C.E. 1980. Personal communication. Dep. of Stat., Texas A\&M, College Station, 77843.

Gould, F.W. 1975. Texas Plants. A checklist and ecological summary. Texas Agr. Exp. Sta. MP-585:121 p.

Krefting, L.W., and H.L. Hansen. 1969. Increasing browse for deer by aerial applications of 2,4-D. J. Wildl. Manage. 33:784-790.

McKenney, R.S. 1978. Chronic effects of a herbicide strip treatment on habitat use by white-tailed deer (Odocoileus virginianus) on the Rio Grande Plains, Texas. M.S. Thesis. Texas A\&M Univ., College Station. $66 \mathrm{p}$.

McMahan, C.A. 1973. Use of Rio Grande Plain brush types by white-tailed deer and analysis of influents. Ph.D. Thesis. Texas A\&M Univ., College Station. $105 \mathrm{p}$.

McMahan, C.A., and J.M. Inglis. 1974. Use of Rio Grande Plain brush types by white-tailed deer. J. Range Manage. 27:369-374.

Marshall, R.N. 1978. Early chronic responses of white-tailed deer(Odocoileus virginianus) to an $80 \%$ herbicide strip treatment of brush on the Rio Grande Plain, Texas. M.S. Thesis. Texas A\&M Univ., College Station. $131 \mathrm{p}$.
Meyer, R.E., and R.W. Bovey. 1973. Control of woody plants with herbicide mixtures. Weed Sci. 21:423-426.

Powell, J., and T.W. Box. 1966. Brush management influences preference values of south Texas woody species for deer and cattle. J. Range Manage. 18:247-250.

Scifres, C.J. (Ed.). 1973. Mesquite. Tex. Agr. Exp. Sta. Res. Mon. 1:84 p. Scifres, C.J. 1980. Brush Management. Principles and Practices for Texas and the Southwest. Texas A\&M Univ. Press, College Station. 360 p.

Scifres, C.J., G.P. Durham, and J.L. Mutz. 1977. Range forage production and consumption following aerial spraying of mixed brush. Weed Sci. 25:48-54.

Steel, R.G.D., and J.H. Torrie. 1960. Principles and Proced ures of Statistics. McGraw-Hill Co. Inc., New York. 481 p.

Tanner, G.W. 1976. Early effects of an $80 \%$ herbicide strip treatment on habitat use by white-tailed deer(Odocoileus virginiamus) on the northern Rio Grande Plain, Texas. M.S. Thesis. Texas A\&M Univ., College Station. $106 \mathrm{p}$.

Tanner, G.W., J.M. Inglis, and L.H. Blankenship. 1978. Acute impact of herbicide strip treatment on mixed-brush white-tailed deer habitat on the northem Rio Grande Plain. J. Range Manage. 31:386-391.

Vallentine, J.F. 1971. Range development and improvements. Brigham Young Univ. Pres, Provo, Utah. 516 p.

Whitson, R.E., and C.J. Scifres. 1980. Economic comparisons of alternatives for improving honey mesquite-infested rangeland. Tex. Agr. Exp. Sta. Bull. 1037. 185 p. 